Table 1 shows the minimum transmittatice of the sol-gel malerial within a broat spectrum renging from UV to short-wave infiared. Within the narrower bandpass of $400.1100 \mathrm{~mm}$, the mintmum transmittunce of the 27,5 tum thick and 17,8 um thick lijhs was 92 and $97 \%$, respectively.

The thean RMS surfice rongluess values after development listed in Table 1 correspond to a lotal integtated scatter of 10 and $11 \%$ at $587 \mathrm{~cm}$ [4].

The maximum pallertued thickness of the hybriat glass materiat described in Table I can be interpreted in terns of a reftactive or at tellective micro-opticat element. With a $1.2 \mathrm{~mm}$ clear aperture, a refractive lensict can be fabricated will an effective focal length $(f)$ of $21 \mathrm{~mm}$ and a numerical aperture $(N A)$ of 0.03 . With a $600 \mu m$ clear aperture, it rofractise lenslet can be fabriented with $f_{t}$ $=5.25 \mathrm{~mm}$ and $N A=0.06$. With a $600 \mu \mathrm{m}$ clear aperture, a concave micromirror can be fabricited with $f_{a}=1.3 \mathrm{~mm}$ and $N A=$ 0.23

The maximum patterned depths listed in lable I were uniformly achieved within wide features and within the narrowest features on the pholomask used to ereate the slement slown in Fig. 1. The narrowest patterned zone of the wone plate in Eig. 1 has a radial width of $27.5 \mu \mathrm{m}$ sesulting in an aspect ratio of 0.6

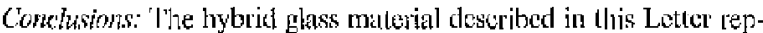
resents a step towards obtaining the material properties required by the simultancous fabrication of oplica! and opto-nnechanical features in nticro-optical systens. In addilion, this hybrid ghass material cxlybits superior sensitivity to UV light allowing the fabrisution of $17 \mu \mathrm{m}$ deep structures after only a $0.5 \mathrm{~s}$ exposule. Future efforts will be directed towards patterning this hybrid glass material with a grey-scale photomisk to reallise nore complex micro-opto-medhanical structures.

Acknowledgmonts: R, Lewy is supported by the Optical Datit Storage Center at the Oplietl Sciences Center, Utriversity of Arizona.

\section{S IEE 2000}

24 Jmarary 2000

Electroniss faters Online No: 20014420

DOI. 10.1049/4t:20100429

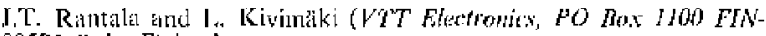

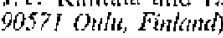

R. 1,ewy and M.R. Descour (Optical Sciencen Center, 7he Uhiversity of Arizind, Tucson, $A Z 85721$, USA)

\section{References}

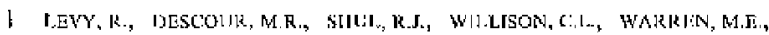
KOIOI.JOMA T., and RANIALA, J.: 'A concept for zero-aliphment miero optical systems', Proc. SPllE, Microméchime 'Technology for Difltrictive and Holograplic Optics, September 1999, Vol. 3879, pp. $167-173$

2 WU, M.C, YIN, L.Y., I.JF, S.S., and KINGi, C.R.: 'Frec-space integrated

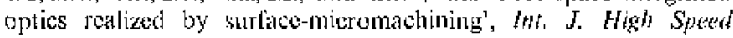
Electron. Syat. 1997, 8, (2), pp. 283-297

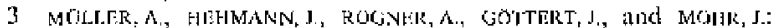
'Tlybrid opticel tratsceiver module with a micro optical LIGAlyonch'. Patper Tu.P. 23, Proc. 2lst European Conf. Opt. Comin., LCOC $95,1995,0 \mathrm{p}, 465-468$

4 KIMMEL, R.K., and PAEKS, R.E. (F.dS.): 'Surfine texure' in "ISO 10110 Optics and nptical instruments' (Optienl Sociely of America, 1995), Chap : 8

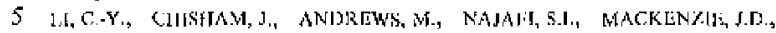
and PYGHAMmkLN, 3.: "Sol-gel integrated optical coupler by ultraviolet light imprinting', F/cotron. I.ett. 1995, 31, (4), p). 271272

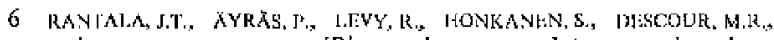
and PLYCHAMBARIAN. N.: 'Bintry-phase zone-plate arrays based on trybrid solpel glass", Opt. Leth, 1998, 23, (24), pp. 1939-1941

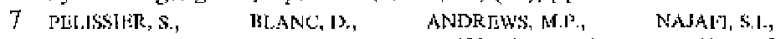
TICICHESKO. A.\%, and I'ARRINUX, 0: 'Single-sicp UIV recordjug of sinusoidal sulface gratings in hybritl solgel glasses', Ajpt. Opt, 1999, 38. (32), pp. 6744-6748

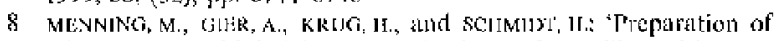
micropatterns with heights up to 30 microls from silica sols', l' roc, Sl'll, Sol-Gel Opties IV, 199?, Vol. 3136, pi. 480-485

9 AYRAS, l', RANTALA, J.T, GIYY, R, PHSCOUR, M.R, HONKAKEN, B.,

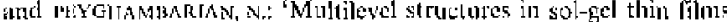
with a single UV-exposure using it grty-seale mask', Thin Solid Fitms, 1999, 352, (1-2), pp. 9.12

\section{Polarisation-independent Bragg gratings in ion-exchanged glass channel waveguides}

D.F. Geraghly, D. Provenzano, M.M. Morrell, J. Ingenhoff, B. Drapp, S. Itonkanen, A. Yariy and N. Peyghambarian

The polarisation dependence of Bragg gralings pholowstiten in ion-exchuged glas wavelides is chatucterised for waseguides with diflerent mask-opening widtlis and bucial deptlss. It is bound thiu polarisation-independent gratings can be written in wisveguides with a wide variation in fabrication perantetes.

Bragg reflection gralings in fibre optic communication systems and sensors have demonstraled mumerous applications, such as multiplexing, dispersion compensition and laser fecdback [1]. Their widespreat use is a clear indication of their importance in these fields. Most applications require polarisation-independent operation due to the specitications of the other components in the systems.

Pholowritten lifagg gritings hawe recently becla demonstrated in ion-exchanged channel waveguides, an integrated optics technology currently in commercial use. Single step ion-exchanged wavegnicles have an intrinsic birefringence due to the asymmetry of the wavegride structiric and sitess. T'hin jesults in a strong polatisalion dependence of the Bragg reflection, with the transmission dip for TE and TM separated by $0.56 \mathrm{~nm}$ [2]. Birclingente control in ion-exchanged wavegudes bis been demonsttated by means of at two step jon-exchange process. Howcer, the study showed a nearly linear dependence of the biretringence on the fabrication parameters. This results in a crossing point for zero birefringeno, which can only be achieved by exercising strict control of the fabricalion parameters [3].

In this Letter, we denonstrite polatisation-independent Bragg reflection gratings photowritlen in ion-exchanged waveguides. The birefingence of the waveguides is eliminted through an additionsl step, at ficld assisted burith [4]. This second step buries the waveguide below the surlace of the glass, dechasing the asymmethy of both the wareguide struclure and the stresses. $A s$ at result, it is possible to write a simple liragg grating with identical performance for both Tli and TM polarisations.

The waweguide fabrication is similar to that described in [5]. Five samples were rabricated by silver ion-exchange in BGG31 glass $[6]$, each sample having straight waveguides fabricated from mask openings of $1,1,5,2$ and $2,5 \mu \mathrm{m}$. The samples were then bulied by fiokl-assisted jon-exchange to different depths: $2.8,5.6,8.4$,

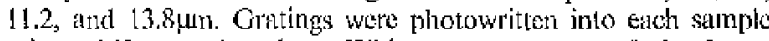
usitig a $248 \mathrm{~nm}$ excimer lascr. With an exposure area ol $-2 \times 2 \mathrm{~mm}$, 5040 . of pulsed exposure wrote gratings of $535 \mathrm{~nm}$ periodicily.

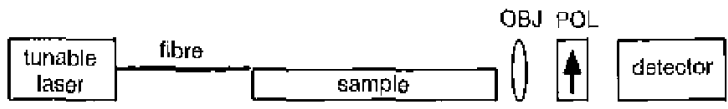

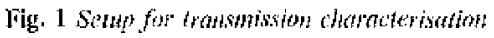

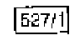

The transmission of ench sample was characterised using the setup shown in lig. 1. Tw output of a tunible laser was fitre butt-coupled to the sample. The waveguide output was collected with a $20 \times$ objective lens and passed through a polatiser to aljow separation of the TE and TM modes before being detected.

The transmission of the samples through the waveguide with the 2 rin mask opening is shown in Fig. 2 for burial deptls of 2.8 , $5,6,8.4$ and 13,8 .un. 'The flat botton cvident on the dip is the result of the linited dynamic range of our moasurement setup. $A$ different setup umable to distingnish polarisations measured a 60dB dip in the tratrsmission on one of our samples. The asymmetric shape results from imperfections in the grating writing process. A slightly Gaussian shape to the beam profilo in the trunsverse direetion will result in al slight Gulussian tpodisation of the grating in the longitudinal dircetion when the beam is not perfectly aligned to the waveguide. This, combined with a negative induced refactive index onange, would yield the asynmetric shape observed [?]. 
Fig. $2 a$ shows a small polarisation dependence temaining for the $2.8 \mathrm{um}$ deep burial. The transmission dip is shifted by $=0.1 \mathrm{~nm}$ from T'E to TM. This is much less than proviously reported polarisation dependence [2], which is surprising for such a short burial depth, although it is still unaceptable for most system applications. This polarisation dependence is quickly reduced as the waveguides are further buried to a deptl of 5.6 um. Fig. $2 b$ shows that this sample has a negligible polarisation dependence of $-0.011 \mathrm{~mm}$. Even this is eliminited witl further bultial. The $8.4 \mu \mathrm{m}$ deep burial, shown in Fig. $2 c$, revenls no measurable polarisation dependence.
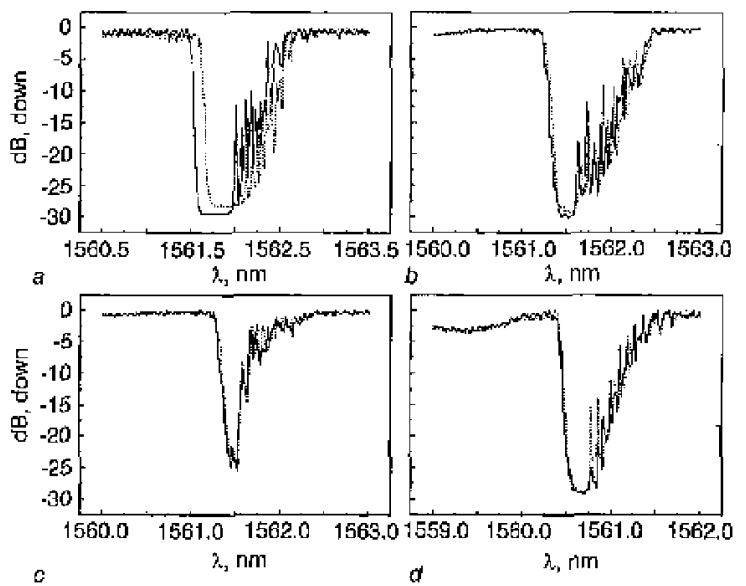

[527/2

Fig. 2 Trathsthision of $2 \mu \mathrm{m}$ mask ortening waveguids with difforem burial depths

Butial depths:

a $2.8 \mu \mathrm{m}$

b $5.6 \mathrm{\mu m}$

c $8.4 \mu \mathrm{m}$

d 13.8 .4117

T...- TH:

TM
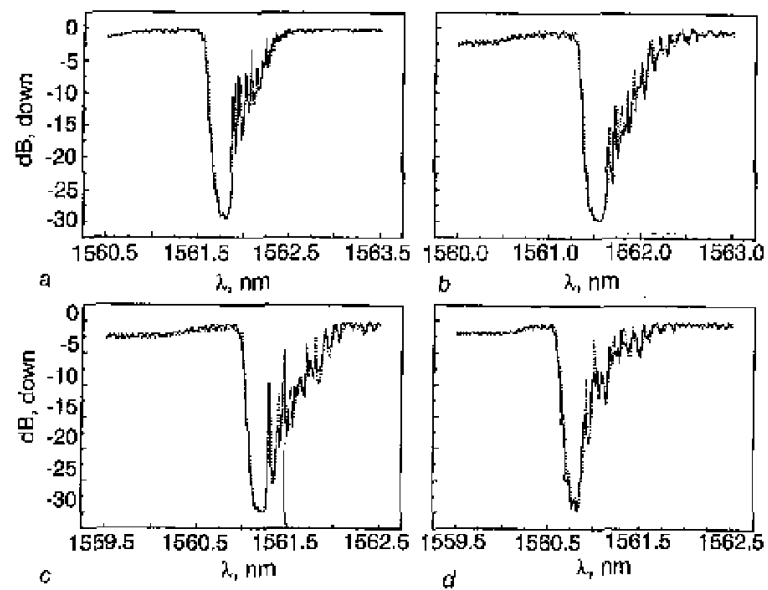

5278

Fig. 3 Transwission of wavegutdes with buriat depth of $11_{2} 2$ wh and differen mosk opening widhs

Mask opening widths:

$\begin{array}{ll}a & 1.0 \mu \mathrm{mi} \\ b & 1.5 \mu \mathrm{m}\end{array}$

c $2.0 \mu \mathrm{m}$

d $2.54 \mathrm{~mm}$

- TF

It is important thet further buritil does not result in increased polarisation dependenco. $A$ s previously mentioned, the bircfingenoe is elinuinated in two ways by the burial prosess. Both the shape of the waveguide and the stresses bccome more symmetric. It was a conern that the waveguide structure asymmetry might diminish mote rapidly, resulting in an opposite bitefringence (the transmission dip for 'TM at longer wavelengths) for deeper butials. Such an eftect would result in a crossing point for polarisationindependent performance, repuiring strict control of the fabrication parameters and limniting the potentially achicvable waveguido structures. However, fig. 2d/shows that continuing the burial to a depth of 13.8 mu still resulted ill a polarisalion-independent grating.

Additionaly it is imporlant to note that the polarisalion clependence was the same for all weveguides of identical burial time, regatdless of the mask-opening width. Fig. 3 shows the characterised transmission through waveguides with $1.0,1.5,2.0$ and $2.5 \mu \mathrm{m}$ wide mask openimgs for a burial depth of $11,2 \mathrm{~km}$. None of the wayeguides showed any significant polarisation depondence. Althongh not slown here, the poldrisation sensitivity of the gratings showed no dependence on the waweguide maskopening widh for all of the burial times characterised.

In conclusion, we have demonstraled polarisation-independent gratings photowritten in ion-exchanged glass waveguides. Waveguide bitefringence is quickly elininated by a second ionexchange step of fieldi-assisted burial, with almost polarisationindependent gratings resulting after just a 5.6 pn deep burial. Additionally, the birefringence remajns negligible with further burial, resulting in a wide range of butial times with polarisationindependent gratings. This allows for greater flexibility in the fabrication paraneters and resulting waveguides.

Acknowledgment: The authors would like to ncknowledge JOT for their partial support of this work through the COEOIP center.

$0 \mathrm{JEE} 2000$

10 Jamary 2000

Electronice I.etters Onine No: 20000473

DOI: $10.104 \% / 20000473$

D.F. Geraglty, M.M. Morrell and S. Honktunen (NP Photonic Technologies, UA Scichee and Technology Powk, 9030 S. Rita Rd, Suite 120, TUKON, AZ $\$ 5747$, USA)

D. Provenzamo and A. Yariv iCalifontio Instiute of Tecimology

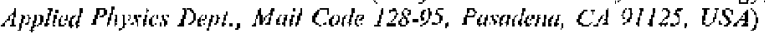

J. Ingenhol? and B. Drapp (IOT Integricrte Optik, GmbH of Co. KG.

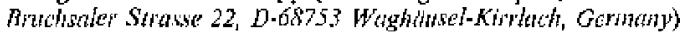

N. Peyphamhatian (University of Arizona. Optical Solonde Center. 16.30 E. University Bivd, Tucsol, AZ 8572I, USA)

\section{References}

1 GILEs, Cre.: 'Lightwave applications of fiber Bragg gratings', $J$ lighwave Techmol, 1997, 15, (8), np. 1391-1404

2 GFRMIITY, D.F., I'ROVIANZANO, D., MAKSIIALL, W.K., IIONKANEN, S,

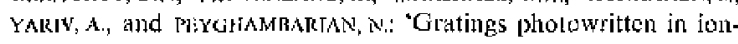
exchanged gless chantrel waveguides', Electron. Lett., 1999, 35, (7), pp. 585.587

3 KYRAS, $\mathrm{P}$, NUNAI CONTI, G, IOONKANEN, S, and PIYYGHAMIIALINN, N.: "Thicfingente control for jon-cxclenged channel glass waweguides", Appl. Opt, 1998, 37, (36), pp. 84008405

4 Buchor. D, 13, and voofs, Li: 'Polarisation insensitive alruyedwaveguide grating nutltiplexers will ion-exchanged waveguikes in gluss', Flectron. Leth, 1996, 32, (24), Pp. 2248.2250

5 NAJAII, S.J, (Ed.): 'Introduction to glass integrated optics' (Norwoos, MA: Atreeh Houne, 1992)

6 FAMRICIUS, N, OFSTH, II, GUTTMANN. I1,-J., QUAST, II., and ROSS, T.: 'BGG 31: A ncw glass for mullimode waveguide fabrication'. Li]OCLAN 88, Anstertim, 1988

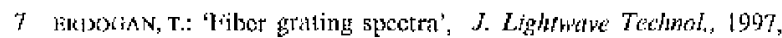
15, (8), pp, 1277-1294 